\title{
THE EFFECT OF A DECISION SUSTAINING A DEMURRER TO A COMPLAINT.
}

In the drawing of a complaint it is the duty of the draughtsman to make the allegations according to the facts as he claims them to be. It is prima facie presumed that competent evidence will be forthcoming at the proper time to establish their truth in case any of them are denied. When a demurrer is filed to a complaint the defendant, for the purposes of the demurrer, admits the truth of the allegations thereof. The questions of law thus raised are submitted to the court for decision. If the demurrer is sustained, the plaintiff may usually amend. In that case no judgment is entered upon the demurrer. If the plaintiff exercises his privilege of amendment, a new fact or series of facts are added to the old complaint, or some of the old ones are omitted, or an entirely new statement is substituted for the one held to be insufficient. If the plaintiff neglects to amend, judgment for the defendant is entered upon the demurrer. It is the effect of the decision sustaining such a demurrer that we desire to consider.

If the plaintiff amends within the requisite time it is very clear that the case stands as if no demurrer had ever been filed. He may then compel the defendant to plead, or he may exercise his right of withdrawal. But it may so happen that before the plaintiff can amend he will be obliged to pay costs as a penalty for his first mispleading and as compensation for the trouble and expense which he has caused the defendant. He may conclude not to do this. An instance of this kind is found in the case of Brennan v. The Berlin Iron Bridge Company, 7 I Conn. 479. In that case the plaintiff brought his action for damages said to have been caused by the negligence of the defendant company, which, as the complaint stated, was building, by contract, a trestle for the Naugatuck Malleable Iron Company. In the course of the work the defendant needed the services of some extra help. Accordingly, two men were loaned by The Malleable Iron Company to assist the defendant's workmen. While so assisting, one of them, Brennan, was injured. Under the Connecticut practice, the case was defaulted by the defendant. The default was afterwards opened and the plaintiff was permitted to amend. To the complaint as amended the defendant demurred because, upon the facts stated, it appeared that Brennan was in the 
position of a servant of the defendant and because it appeared that he was injured by the negligence of a fellow-servant. 'This was a demurrer which went to the substance of the action, and it was sustained by the Superior Court. Afterwards, the plaintiff filed, without leave of the court, and without the consent of the defendant, a substituted complaint. The defendant objected to the allowance of this second amendment and asked that it be erased. The court ordered the substituted complaint stricken from the files, but gave the plaintiff permission to amend upon payment of twenty-five dollars costs. He failed and neglected to amend, but before final judgment was entered up, he filed a notice of withdrawal The defendant, thereupon, moved that the attempted withdrawal be disallowed and that judgment be entered upon the demurrer. The Superior Court granted the motion and ordered that the judgment be entered.

In a suit between the same parties brought a year after the date of this judgment, for damages caused by the same accident, the plaintiff adopted for his complaint, the substituted one that he had filed in the first case, and which was erased by the court, but which he was then permitted to file upon the payment of the costs as just stated. This new complaint contained allegations different from those to which the demurrer had been filed, and the new allegations were not demurrable. The defendant again defaulted the case and claimed upon the hearing in damages that the former judgment upon demurrer was a bar to the prosecution of the second case. The Superior Court overruled this claim and rendered judgment for the plaintiff to recover substantial damages. Upon appeal the Supreme Court held that the first judgment was a bar and reversed the one rendered in the second case to nominal damages.

The first effect in that case of the decision sustaining the demurrer was to prevent a withdrawal thereafter of the suit. No memorandum or opinion was ever filed by the judge who disallowed the withdrawal, and this branch of the case was never considered by the Supreme Court. We believe that the witndrawal was properly disallowed.

The plaintiff, in filing it, was endeavoring to accomplish something in which he ought not to be assisted by the court. Such an exercise of the right of withdrawal ought not to be favored. He was endeavoring to avoid payment of costs, which the court had ordered him to pay, if he wished to go on with the case. To allow a plaintiff to withdraw a case after a full hearing and determination of such a demurrer, would 
$\therefore$ be to put the defendant to considerable trouble and expense. When the parties have framed the issues to be tried and a decision has been rendered thereon, it is vexatious for the defeated party to withdraw the case, and bring a new suit. If a party could bring his case, and submit it to the court for decision, and after decision against him, be permitted to with: draw it and thus be rid of the adverse judgment, it would be not only unjust to the other party, but trifing with the court. If he is not satisfied with the decision let him appeal from the judgment.

The Connecticut statute which permits withdrawals is found at the end of Section 988 of the General Statutes, Revision r888, and provides that "the plaintiff may withdraw any action **

* before the jury have given in their verdict." A verdict of the jury precedes the rendition of the judgment. So that the case was one step further advanced than the verdict of a jury, when the withdrawal was attempted. The demurrer admitted the truth of the allegations of the complaint for the purposes of the demurrer. Upon the argument of the demurrer it was the same as if the jury had brought in a special verdict finding the facts as alleged in the complaint, and a hearing was had before the court as to the judgment to be rendered. A judgment on demurrer is a final judgment and stands as such, unless the complaint is amended, until it is set aside by appeal or proceedings in error. The case had been decided when the attempted withdrawal was filed.

Black says, in treating of the different kinds of judgment, that they may be "for the defendant when the issue raised by a demurrer is determined in his favor. This is a final judgment and disposes of the case, unless leave be granted to amend the pleading, or withdraw the demurrer, as the case may be:" I

Swift says: "Final judgments are rendered at the termination of the suit. They may be rendered upon demurrer, verdict, default, confession, nihil dicit, and nonsuit. r. In demurrers the facts are confessed, and the law only controverted; and the court, on determining the question of law, must render judgment for the party who has the law in his favor. 2. The verdict of the jury ascertains the facts in dispute, and the court must-render judgment for the party in whose favor the law is found." "2

In some states, Connecticut with others, there is no statute which governs cases tried by the court without a jury, and there

II Black on Judgments, sec. 13, par. 3.

II Swift Dig.: P. 783. 
is some variance in the decisions upon the subject. At common law in England, the right of withdrawal continues up to the time that "the judge has pronounced his judgment." " In our Federal Courts it has been held to exist "at any time before the trial is opened to the court." "This rule has been adopted in Maine, Massachusetts and New Hampshire. In Pennsylvania "the argument of a demurrer will put an end to the right to discontinue." A plaintiff in Oregon "is entitled to a voluntary nonsuit at any time before trial." And the court defines the word "trial" to be "the judicial examination of the issues between the parties, whether those issues be of law or of fact.""

In Moriarty v. Mason, 47 Conn. 438, our Supreme Court observes that there are no equities in favor of a party who desires to withdraw a case after it has been decided against him by a committee, which has made out and handed its report to the counsel for the prevailing party. The court held that a withdrawal could not be allowed, although the report had not been accepted, nor judgment thereon rendered, nor the report filed in court.

The second important effect of a decision sustaining a demurrer to matters of substance, which is followed by a final judgment, is that it operates as res adjudicata, and is a bar to any subsequent suit between the same parties for the same cause of action. This is so even if a judgment file has never been drawn. That document is a mere formula which follows the legal determination of the rights of the parties.'

The term "cause of action" has been defined as "matter for which an action may be brought." But the term is often misused and misunderstood. A concrete case may serve to present the subject in a clearer light. In the case of Wildman v. Wildman, $7 \circ$ Conn. 700, the plaintiff and defendant were brother and sister respectively. In a prior suit between them, the plaintiff had alleged that the defendant had in her possession, and had caused to be recorded, two written documents which purported to be deeds conveying certain real estate from the plaintiff to the defendant, and which had never been executed or delivered by. the plaintiff. He asked that the deeds be cancelled and set aside. The parties were at issue as to the non-execution and non-delivery of the deeds. Upon the trial of this case it was

${ }^{3}$ Outhwaite v. Hudson, 7 Ex. Rep. 380.

'Johnson v. Bailey, 59 Fed. Rep. $6 \not 11$.

- Kennedy $\vee$. McNickle, 2 Brewster 537.

- Hume v. Woodruff, 26 Oregon 373, citing Alley v. Nott, III U. S. 472.

7 Clark v. Melton, I9 S. C. 507 ; Ball v. Trenholm, 45 Fed. Rep. 589.

${ }^{8}$ Bouvier Law Dict. (14 ed.) "Cause of Action." 
proved that the deeds were properly executed and delivered, but that the property was put in the sister's name to prevent its being subject to an unlawful claim which might arise against the brother's.estate in case of his death, and that the sister with full knowledge of the circumstances accepted the deeds and that they were utterly without consideration and were afterwards treated as void between the parties. During the progress of this first trial the plaintiff sought to amend his complaint, so as to state the facts as they existed, but the trial court refused to give him that privilege, and rendered judgment for the defendant. In the suit, which was afterwards brought, the plaintiff alleged the facts as they really were. The defendant pleaded the former judgment in bar alleging that the causes of action were the same, and the Superior Court sustained the plea. This judgment was affirmed by the Supreme Court. The causes of action in the two suits were held to be identical.

A cause of action involves an essential right belonging to the plaintiff and a corresponding essential wrong done by the defendant. The right and the wrong may each be simple or complicated. In either case there is but one essential right and one essential wrong. The subordinate facts which go to make up this right and this wrong are not themselves separate causes of action.

In negligence cases the plaintiff, when defeated once, cannot state his case in a different way claiming other acts of negligence for the same accident. The judgment in the first action is a bar to any subsequent suit. There is but one injury, and the plaintiff can have but one cause of action against the defendant. That cause of action is entire and cannot be split up into several causes of action. The plaintiff having litigated that cause of action in his.own way cannot have another day in court.'

The other requisite of a judgment in order that it may operate as a bar to another suit for the same cause of action between the same parties, is that the judgment should be upon the merits.

An argument upon a demurrer to a complaint, which sets up a certain state of facts from which it appears affirmatively that. the plaintiff has no ground of recovery, is a trial of the case upon its merits, and a judgment sustaining the demurrer is a judgment on the merits. ${ }^{10}$

It frequently happens that a defendant files an answer which sets up matters in confession and avoidance of those

- Burritt v. Belfy, 47 Conn., 327.

${ }^{10}$ Alley v. Nott, III U. S. 475 . 
alleged in the complaint, and that this answer is demurred to by the plaintiff, and the demurrer sustained. Courts have made a distinction between a judgment rendered upon such a demurrer sustained, and one rendered upon a demurrer to the complaint. The ground for the distinction being that in the former case the defendant has admitted for all purposes the truth of the allegations of the complaint by not having denied them, and that the judgment sustaining a demurrer to the answer leaves the case without any answer and that the judgment is really rendered either upon default or by confession.

There are a large number of cases, in which it has been held that a judgment rendered upon a demurrer for want of material allegations in a complaint is only conclusive upon the identical state of facts alleged, and that such a judgment does not prevent another action wherein the material facts are supplied, although the suit is for the same cause of action. In other words, if the facts are stated in a different manner in the second action which is not demurrerable, it is maintained that the former judgment is not a bar. It is admitted that it would be a bar had the former judgment been upon pleadings and proofs. The case of Wiggins Ferry Company v. O. \& M. Ry., I42 U. S. 4ro, is an example of this class of cases. But we believe, when a judgment is rendered sustaining a demurrer to a complaint, not for any want of material allegations, but because, upon the positive allegations therein contained, it appears that the plaintiff has no right to recover, that such a judgment is a bar to any subsequent suit for the same cause of action. ${ }^{11}$ Such a demurrer does not raise issues which are technical or merely formal, but ones which go to the merits of the action. It is the same as if the defendant in the former case had denied the truth of the allegations of the complaint and a trial had taken place, and the court had found all the allegations of the complaint true, and made a finding in the exact language of the complaint, and then the defendant had claimed that though the facts were as the plaintiff alleged, still he has not entitied to recover. The plaintiff would have no cause to complain because the court had found the facts just as he claimed them to be.

Does the fact that a judgment was rendered upon demurrer prevent its being a bar or an estoppel? Nemo debet bis vexaripro una et eadem causa, is a most salutary maxim, and as a rule of public policy should receive a liberal construction. It matters little how the facts are arrived at, whether by trial or by an agreed statement, or by an admission of their truth. A plaintiff surely

"Gould v. Evansville, etc., R. R. Co., 9I U. S. 532-534. 
ought not to object that the facts are of record just as he has alleged them to be, and as he permits them to remain, when final judgment is rendered upon them.

If this is not so, a plaintiff, having been defeated upon a substantial demurrer and without further amendment, suffering final judgment to go against him, may bring a second suit, changing slightly the allegations, and will be entitled to another trial, and if defeated again, may bring a third suit, and so on indefinitely, until prevented by the statute of limitations.

It is the duty of the plaintiff to allege all the facts connected with the transaction in his original compiaint. After the demurrer is sustained he may generally amend. If he fails and neglects to embrace the opportunity, it is presumed that he desires to stand upon the facts as he has alleged them.

We think a judgment, rendered upon a demurrer to positive facts which appear in the complaint, is, and ought to be, as binding as a judgment after verdict finding those same facts. Where a demurrer is interposed and sustained because of lack of allegations, then the judgment is not upon the merits, and is not a bar. But where a plaintiff sets up certain positive facts and asks the court for a determination of his rights thereon, and a demurrer properly raises the merits of the case, a final judgment upon those merits ought to be binding upon both parties and prevent further litigation upon the same cause of action between them. It should prevent the plaintiff from stating his facts in a different way and having another trial thereon. He is presumed to have alleged them correctly in his first action, otherwise courts will become tribunals to try mooted and imaginary, instead of actual, questions.

Gould, in his work on Pleading, says: "A judgment rendered upon demurrer is equally conclusive (by way of estoppel) of the facts confessed by the demurrer, as a yerdict finding the same facts would have been; since they are established, as well in the former case as in the latter, by way of record. And facts thus established, can never afterwards be contested between the same parties, or those in privity with them."'s The principles here sought to be maintained are supported by several decisions, and by at least two writers of text-books. ${ }^{23}$

19 Gould on Pleading, chap. IX, part I, sec. 43.

13 Gould $\nabla$. Evansville 'R. R. Co., 9I U. S. 543; Alley v.'Nott, III U. S. 475; Bissell v. Spring Valley Township, I24 U.S. 225; Lamb v. MIcConkey, (Iowa) 40 N. W. 77 ; Coffin v. Knott, 2 Green (Iowa) 582 ; Kleinschmidt v. Binzel, I4 Bront. 3I; sc. 43 Amer. St. Rep. 604; Strain v. Illinois Central R. R. Co. (Miss.) I8 So. 847; Bigelow on Estoppel (5th ed.) p. 56 ; I TanFleet's Former Adjudication, p. 322, sec. Iog. 
Suppose a man brings his action for damages caused by injuries resulting from the negligence of a railroad company, and in his complaint it appears that he is a servant of the defendant and was injured by the negligence of a fellow-servant, and that the defendant filed no demurrer but defaulted the case and had a hearing in damages. In that hearing, suppose the court had found the facts in the exact language of the complaint, and had rendered judgment for the recovery of nominal damages. Would not such a judgment be a bar to any subsequent action for that injury? We understand the difference between such a judgment and one upon demurrer to positive facts alleged, to be that upon the sustaining of the demurrer leave is usually given to amend. But if the plaintiff fail to amend, either of his own election, or because the court refuses to allow him to do so, and he suffers final judgment against him, and fails to appeal, he then stands upon the same footing as in the case of judgment on a hearing in damages and is preciuded from again putting the defendant to the annoyance of another suit for the same injury. He has had his day in court, litigated his case in his own way, and had it decided.

If the demurrer had been overruled and the defendant had failed to plead over, judgment would have gone for the plaintiff on demurrer overruled. It makes no difference whether the plaintiff in that case could have recovered substantial damages or only nominal damages, the effect would be the same, and the plaintiff would have been precluded from bringing another action for the same injury.

Our conclusion, therefore is, that after a substántial demurrer to affirmative allegations in a complaint has been sustained, the plaintiff by failing to take advantage of his privilege to amend, and to make his original action good, has waived his rights. The judgment becomes conclusive upon him, and is a bar to any subsequent suit for the same cause of action.

New Haven, June 18th, 1900.

Seymour C. Loomis. 